KEMAS 14 (3) (2019) 353-358
Jurnal Kesehatan Masyarakat

\title{
Hospital Fire Risk Analysis with Hazard, Vulnerability, Capacity, Risk Assessment Model
}

\author{
Sisca Mayang Phuspa ${ }^{1 \bowtie}$, Mustafal Kamal ${ }^{1}$, Eka Rosanti ${ }^{1}$ \\ ${ }^{1}$ Program Studi D4 Keselamatan dan Kesehatan Kerja Universitas Darussalam Gontor Ponorogo, Indonesia
}

\begin{tabular}{l} 
Article Info \\
\hline Article History: \\
Submitted May 2018 \\
Accepted November 2018 \\
Published March 2019 \\
\hline Keywords: \\
Risk Analysis, Fire, Hospital \\
\hline DOI \\
https://doi.org/10.15294/ \\
kemas.v14i3.14269
\end{tabular}

\section{Introduction}

Fire is one among the threat to a building that should be prevented to reduce the risk of material or non material loss, as instructed by the government in Undang-Undang RI No 28 Tahun 2002 regarding Building. Many building with various purpose, generally has fire potential. Among the building with fire risk is the hospital building.

The fire at the hospital could have a high risk due to the activity in community health service. Hospital uses the materials and medical tools that can be a cause factor. Beside, mosth of the residents are patient with weak physical ability and require assistance to evacuate them selves (Arrazy et al, 2014).

Fire incidents at the hospital were several times occured in Indonesia. One was in 2014, as reported in news.detik.com (Januari 3, 2014). There was a fire incident in the operating room on one of Ponorogo Regional Hospital. Though it was not cost any life, still it cause a material loss to the hospital.

In 2015 the Ponorogo Regional Hospital had been completeley accredited by Ministry of Health. The accreditation is purposed to measure how far the hospital comply to the standard settled by the government in the effort to maximalize health service (Maharani, 2009). Definitely the accreditation does not instantly wipe out the fire potential. Beside, UndangUndang RI No 44 year 2009 regarding hospital obligate protection system to prevent and overcome fire incident for safety of all patient and related residents. Since then this research is importantly conducted. 
Li and Huang (2012), Ding (2013), Li et al (2013), Tofiło et al. (2013), Xin and Huang (2013), Zhang et al. (2016), and Zhang (2018) has same opinion that risk analysis is required to minimize loss in case of fire incident. The analysis result can be used as reference in a better fire protection system plan ( $\mathrm{Li}$ and Huang, 2012). Fire risk analysis involving responsible employee of the building can improve institution capacity in fire fighting (Ding, 2013). Fire risk analysis result should be communicated to all stake holder in the building to improve their awareness and readiness to fire threat (Zhang et al., 2016).

Fire risk analysis can be done with several methods or approaches. This is relied on the point of view to the factors affecting risk level. The AS/NZS 4360:2004 risk management concept stated the risk level is determined by level of probalility/likelihood and scale of impact or severity dan be caused (consequences/severity).

Other concept is HVCRA model (Hazard, Vulnerability, Capacity, Risk Assessment) adopted by Disaster Prevention National Board (Badan Nasional Penanggulangan Bencana/ BNPB) in 2012 General Reference of Disaster Risk Study (Pedoman Umum Pengkajian Risiko Bencana tahun 2012). Risk is the result of quantification aligned with hazard and vulnerability factor while it is inversed with capacity factor. This research particularly study the fire hazard factor. Vulnerebility factor in a disaster involves object element exposed to hazard risk, in this case is the present of hospital patients. Capability factor is all effort whether the procurement of physical or non physical facility to confront disaster threat (Windraswara, 2009). In this research the focus is on the building fire protection system.

This concept is applied in the research since the risk can be deeply studied and involve increasing and decreasing factor. Disaster risk study can be assessed semi-quantitatively by using proportioning factor and index value, not real value.

\section{Method}

The research is a case study with descriptive analitic property to describe an object (Ponorogo Regional Hospital) on present time and the relation with a phenomenon (fire disaster) sistimatically, factual and accurate. The population in this research is the whole units (27 rooms) in Ponorogo Regional Hospital that is a unity object, thus the sampling used total sampling method. Room or unit in this research ia Polyclinic, Nutrition Instalation, Laundry, CSSD, Power Room, Warehouse, Waste Treatment Instalation, Generator Room, Indoor Cafetaria, Outdoor Cafetaria, Emergency Room, Blood Bank, Office Room, Aster Inpatient Room, Flamboyan Inpatient Room, Mawar Inpatient Room, Radiology, Laboratory, ICU, Operating Room, Teratai Inpatient Room, Delima Inpatient Room, Tulip Inpatient Room, Melati Inpatient Room, Dahlia Inpatient Room, Seruni Inpatient Room, Lobby.

Data collection is conducted by observation, interview and document study. The data is analyzed with disaster risk study based on treat, vulnerability and capacity method by refering to Pedoman Umum Pengkajian Risiko Bencana (General Reference to Disaster Risk Study) in Perka BNPB Number 2 year 2012 yet specify on hospital fire risk. The risk level assessment (low, medium, high) based on treat, vulnerability and capacity variables is done with proportioning and scoring, as described in Table 1.

Those three variables hazards, vulnerability and capacity value from above proportion and scoring process then being inputted in risk index mathematic model below:

\section{Risk $=($ Hazard $x$ Vulnerability $) /$ Capacity}

The risk index total calculation will gain a value determining risk level on each unit (room) in Ponorogo regional hospital, with indexation low ( score $0-0.33$ ), medium (score $0.34-0.66$ ) and high ( score $0.67-1.00$ ).

\section{Result and Discussion}

Regional Hospital in Ponorogo researched is the one had been completely accredited in 2015. The hospital has 27 rooms or units divided onto 3 groups which are general service units, inpatient care units and supporting units. Service units consist of patient registration lobby, polyclinics, administration office, nutrition installation and cafetaria. Inpatient groups consist of room class I, II, III, IV and VIP. The last group is supporting units consist of laboratory, waste treatment 
Table 1. Index Conversion Parameter and Equation

\begin{tabular}{|c|c|c|c|c|}
\hline Variable & Class Parameter & $\begin{array}{l}\text { Score } \\
\text { Class }\end{array}$ & Proportion & Total Score Equation \\
\hline \multicolumn{5}{|c|}{ Fire Risk Potentional Analysis (H) } \\
\hline $\begin{array}{l}\mathrm{H} 1: \text { The } \\
\text { presence of } \\
\text { flammable goods }\end{array}$ & $\begin{array}{l}\text { Low : No flammable goods } \\
\text { Medium : There is fire causing substance and } \\
\text { arranged as standard } \\
\text { High : There is fire causing substance and not } \\
\text { arranged as standard }\end{array}$ & $\begin{array}{l}0,333 \\
0,667 \\
1,00\end{array}$ & $50 \%$ & \multirow{2}{*}{$\begin{array}{l}\text { Hazards Index }=\left(0,5^{\star}\right. \\
\mathrm{H} 1)+\left(0,5^{\star} \mathrm{H} 2\right)\end{array}$} \\
\hline $\begin{array}{l}\mathrm{H} 2 \text { : Electrial } \\
\text { Installation is } \\
\text { comply to SNI } \\
0225: 2011\end{array}$ & $\begin{array}{l}\text { Low : comply to the standad } \\
\text { Medium : comply to the standard but without } \\
\text { technical review } \\
\text { High : not comply to the standard }\end{array}$ & $\begin{array}{l}0,333 \\
0,667 \\
1,00\end{array}$ & $50 \%$ & \\
\hline \multicolumn{5}{|c|}{ Vulnerability Factor Analysis (V) } \\
\hline $\begin{array}{l}\text { V1 : Population } \\
\text { Density }\end{array}$ & $\begin{array}{l}\text { Low : If room space (unit) per-person } \geq 9 \mathrm{~m}^{2} \\
\text { High : If room space (unit) per-person }<9 \mathrm{~m}^{2}\end{array}$ & $\begin{array}{l}0,00 \\
1,00\end{array}$ & $50 \%$ & \multirow[b]{2}{*}{$\begin{array}{l}\mathrm{V} \text { Index }= \\
\left(0,5^{\star} \mathrm{V} 1\right)+\left(0,5^{\star} \mathrm{V} 2\right)\end{array}$} \\
\hline $\begin{array}{l}\text { V2 : Patient } \\
\text { occupation }\end{array}$ & $\begin{array}{l}\text { Low : If room space (unit) is allocated for non } \\
\text { medical activity } \\
\text { High : If room space (unit) is allocated for } \\
\text { medical activity }\end{array}$ & $\begin{array}{l}0,00 \\
1,00\end{array}$ & $50 \%$ & \\
\hline \multicolumn{5}{|c|}{ Capability Factor Analysis (C) } \\
\hline $\begin{array}{l}\text { C1 : Light fire } \\
\text { ext ing u i s h e r } \\
\text { compliance to } \\
\text { SNI 03-3987- } \\
1995\end{array}$ & $\begin{array}{l}\text { Low : if fire extinguisher compliance } \\
\text { percentage } \leq 33 \% \\
\text { Medium : if fire extinguisher compliance } \\
\text { percentage } 34-66 \% \\
\text { High : if fire extinguisher compliance } \\
\text { percentage } \geq 67 \%\end{array}$ & $\begin{array}{l}0,333 \\
0,667 \\
1,00\end{array}$ & $25 \%$ & \multirow{4}{*}{$\begin{array}{l}\text { C Index }= \\
\left(0,25^{\star} \mathrm{C} 1\right)+\left(0,25^{\star} \mathrm{C} 2\right)+ \\
\left(0,25^{\star} \mathrm{C} 3\right)+\left(0,25^{\star} \mathrm{C} 4\right)\end{array}$} \\
\hline $\begin{array}{l}\text { C2 : } \text { Sprinkler } \\
\text { compliance to } \\
\text { SNI } \quad 03-3989- \\
2000\end{array}$ & $\begin{array}{l}\text { Low : if sprinkler compliance } \leq 33 \% \\
\text { Medium : if sprinkler compliance } 34-66 \% \\
\text { High : if sprinkler compliance } \geq 67 \%\end{array}$ & $\begin{array}{l}0,333 \\
0,667 \\
1,00 \\
\end{array}$ & $25 \%$ & \\
\hline $\begin{array}{l}\text { C3 : Hydrant } \\
\text { compliance to } \\
\text { SNI } \quad 03-1745- \\
2000\end{array}$ & $\begin{array}{l}\text { Low : if Hydrant compliance } \leq 33 \% \\
\text { Medium : if Hydrant compliance } 34-66 \% \\
\text { High : if Hydrant compliance } \geq 67 \%\end{array}$ & $\begin{array}{l}0,333 \\
0,667 \\
1,00 \\
\end{array}$ & $25 \%$ & \\
\hline $\begin{array}{l}\text { C4 : Detector } \\
\text { and alert } \\
\text { compliance } \\
\text { SNI to } \\
2000\end{array}$ & $\begin{array}{l}\text { Low : if system compliance } \leq 33 \% \\
\text { Medium : if system compliance } 34-66 \% \\
\text { High : if system compliance } \geq 67 \%\end{array}$ & $\begin{array}{l}0,333 \\
0,667 \\
1,00\end{array}$ & $25 \%$ & \\
\hline
\end{tabular}


installation, emergency room, operation room, blood bank and electrical installation room.

Each room in the researched hospital has fire cause factor. Based on the fire theory, the element of fire consists of heat, oxygen and flammable materials. Heat and oxygen factor is ignored in this research due to hardly controlled and unable to be eliminated. When the hazard factors able to cause a fire incident based on identification result on 27 unit researched on Ponorogo Regional Hospital are : (a) 33\% units have phyiscal factor causing fire incident which are flammable materials (stacks of documents) and radiation (medical treatment equipments); (b) $85 \%$ of the units have fire-causing chemical factor, which are flammable substance (desinfectant, reagent, etc) and explosive (pressurized gas); (c) 40.7\% of the units have electricity instalation with low compliance to SNI 0225:2011 (less than 50\%); (d) $22 \%$ of the units have 3 fire-causing factors, $52 \%$ have 2 factors and the rest $26 \%$ have 1 factor in the same room.

Xin dan Huang (2013) stated physical factor is the fuel in fire triangle. Physical factor in form of document papers carelessly managed can increase the fire spread potensial. 5S socialization on materials that easily transferred the fire to others can reduce the risk of large fire incident (Ding, 2013). Based on observation result can be known that $5 \mathrm{~S}$ on the rooms has not been well applicated. Management will to improve $5 \mathrm{~S}$ system on Ponorogo regional hospital can reduce the fire risk potential.

Chemical substance is common materials found in the hospital. Nearly all medical activity use chemical substance, like desinfectant, anticeptic, detergent, reagent, cytotoxic medicine and medical gases. 15\% units which not have chemical substance in the room is non medical (administration, offices and public facility). Zhang (2018) said the unproper chemical management become the cause of many explotion and fire incidents. Clear, accurate, monitoring and comprehensive evaluation of risk assestment in the Material Safety Data Sheet (MSDS) can reduce the potential of fire incident caused by chemical substance (Li dan Huang, 2012). Chemical substance management in the hospital also related with $5 \mathrm{~S}$ system. This is support the argumentation that $5 \mathrm{~S}$ implementation is highly important to be done in the hospital, not only by socialization but also through monitoring and evaluation.

Xin and Huang (2013), Li et. al. (2013) and Rahmawati et. al. (2016) concluded in their research that electrical installation does not comply with the standard is the cause of fire oftenly happen on single building or housing. Monitoring and maintenance complying to SNI 0225:2011 along with wise electrical consumption would avoid the fire potential. The fire incident on Ponorogo Regional Hospital in 2014 also suspected to be caused by electrical short circuit. That incident should be particular evaluation to the management to fix the electrical installation system.

The vulnerability factor according to BNPB guidance in 2012 is grouped onto physical, economical, environmental, and socio cultural vulnerability. In this research it is limited on space physical vulnerability (population density) and patient occupation. The patients are considered as the most risky group threated by fire incident.

Vulnerability analysis result on Ponorogo Regional Hospital is as follow : (a) $52 \%$ units (rooms) are considered vulnerable due to there are inpatients having physical limitation and requires assistance during fire emergency situation; (b) $77 \%$ rooms are consider dense with average space $9 \mathrm{~m}^{2} /$ person; (c) $30 \%$ rooms are considered to have high vulnerability to fire risk due to the inpatients occupation and dense population.

The patients are unseparateable element of hospital as it's function as health service institution. Thus to reduce the patient is not wise recommendation to decrease fire risk level. The contigency plan and emergency response simulation involving all components under the hospital management is one of the effort to increase the readiness to such condition (Karimah et al., 2016). The arrangement of contigency plan and simulation is one of the effort to increase the capacity to provide the protection to the patient.

The population density always be a challenge in fire fighting management (Rahmawati et al., 2016). The high density will cause difficulty during evacuation when the 
object to be evacuated does not well prepared in fire emergency. The communication and coordination of contigency plan to all stakeholder is an effort to minimize the risk (Ding, 2013). Patient density reduction can be done by rearrangement of inpatient room. Along with the reduction then the evacuation during fire incident will be more effective and efficient.

The definition of capacity in BNBP disaster risk concept is the ability of an institution to perform the act to reduce the loss potential due to the disaster. Capacity factors are grouped onto two, which is physically and non-physically. The physical ability is easier to be observed and measured compared to nonphysical. While ability from fire disaster point of view generally manifested in active and passive fire protection system. In this research the ability measured only referred to the proper active fire protection system (Light extinguisher, hydrant, sprinkler, alarm and detector) only. This is due to technical improvement recommendation will be easier to be implemented in active fire protection system than the passive one (Lestari dan Amaral, 2008).

The result of Ponorogo Regional Hospital capacity are as follow : (a) Average light extinguisher compliance to SNI 03-39871995 in all units (rooms) are 89\%. This is caused by irregular maintenance thus several light extinguisher is expired and out of service. (b) average sprinkler complience to SNI 03-39892000 in all units (rooms) is $0 \%$. This is due to the informant can not presents installation and maintenance document for the sprinkler in Ponorogo regional hospital, while the sprinkler network is difficult to be directly observed. (c) Average hydrant compliance to SNI 03-17452000 is $20 \%$. This is due to hydrant maintenance management is not a priority due to economical consideration. Fire fighting still rely to local Integrated Fire Fighter Unit during the emergency situation. (d) Average detector and alarm compliance to SNI $03-3985-2000$ is $72 \%$. This is due to the maintenance management is not a priority in Ponorogo Regional Hospital.

Fire protection system without regular and systematic maintenance can increase the loss risk caused by fire incident. There is no other recomendation than the improvement of active fire protection system maintenance on Ponorogo Regional Hospital. The improvement of the active fire protection system maintenance will undoubtfully give effect to hospital overational cost. Yet it will be worth with the safety level against fire emergency. Budget allocation to maintain the fire protection system is among the management commitment to applicate health and safety work management system on Ponorogo Regional Hospital.

Risk level analysis is done by quantification of index value from analysis result of hazard $(\mathrm{H})$, Vulnerability $(\mathrm{V})$ and Capability (C) factor with mathematical model $\mathrm{R}=(\mathrm{HxV}) / \mathrm{C}$. The assestment of fire risk level on all researched units is exposed in the table on attachment 1. Based on analysis result, researched object shows $18.5 \%$ units have high risk, $59.3 \%$ have medium risk, while the rest $22.2 \%$ have low risk. The room having high fire risk like CSSD, warehouse, electrical installation room, operating room and TPP. The room having medium fire risk like inpatient room Tulip, Delima, Teratai, ICU, laboratory, radiology, inpatient room Mawar, Flamboyan, Aster, Emergency Room, waste management installation, nutrition room and polyclinic. The last is room having low risk like laundry room, cafetaria, blood bank, Melati Room, Dahlia room; Though the high risk rooms have smaller percentage, yet it is not a reason to ignore research recommendation, since the task to keep patient safety is the obligation of the hospital as instructed in Undang-Undang RI No 44 Tahun 2009 about Rumah Sakit.

\section{Conclussion}

This research conclude that though Ponorogo Regional Hospital had obtained complete acreditation, yet there are still units (rooms) having high risk fire risk (18.5\%). This can be caused by hazard potential than doest not properly managed as well as fire protection system that is not comply to the standard.

The patient is the vulnerable group that should obtain more attention particularty during fire emergency situation.

The flammable materials management with $5 \mathrm{~S}$ system is recommended to Ponorogo Regional Hospital to reduce the potential of fire. The maintenance of facility and infrastructure of fire protection system also need to be done 
as standard along with contigency plan and fire emergency respond involving all stakeholders to increace the readiness of the staffs and patients thus victim can be avoid.

This research has limitation which is it has not describe spacially (mapping) the fire risk on each unit. Risk mapping will assist communication and socialization to the related stakeholders. The mapping result with spacial information can also assist to determine the program to control hazard source effectively and efficiently (Dt.Mangguang, 2015). The recommendation for next research is to develop the analysis result to spacial information assisting in fire fighting program socialization and planning.

\section{Reference}

Arrazy, S., Sunarsih, E., \& Rahmiwati, A., 2014. Penerapan Sistem Manajemen Keselamatan Kebakaran Rumah Sakit DR. Sobirin Kabupaten Musi Rawas Tahun 2013. Jurnal Ilmu Kesehatan Masyarakat, 5(2), pp. 103111.

Ding, H. J., 2013. Fire Risk Analysis of Communication Room and Some Suggestions. Procedia Engineering, 52, pp. 88-91.

Dt.Mangguang, M., 2015. Risk Factors Of Malaria Incidence With Spasials Approaching. Jurnal Kesehatan Masyarakat, 10(2), pp. 129-136.

Karimah, M., Kurniawan, B., \& Suroto., 2016. Analisis Upaya Penanggulangan Kebakaran Di Gedung Bougenville Rumah Sakit Telogorejo Semarang. Jurnal Kesehatan Masyarakat (e-Journal), 4(4), pp. 698-706.

Lestari, F., \& Amaral, Y., 2008. Audit Sarana Prasarana Pencegahan Penanggulangan Dan Tanggap Darurat Kebakaran Di Gedung Fakultas X Universitas Indonesia Tahun
2006. Makara Teknologi, 12(1), pp. 55-60.

Li, J., \& Huang, Z., 2012. Fire and Explosion Risk Analysis and Evaluation for LNG Ships. Procedia Engineering, 45, pp. 70-76.

Li, X., Zhang, X., \& Hadjisophocleous, G., 2013. Fire Risk Analysis of a 6-storey Residential Building Using CU Risk. Procedia Engineering, 62, pp. 609-617.

Maharani, C., 2009. Sistem Manajemen Mutu Iso 9000 Sebagai Alat Peningkatan Kualitas Organisasi Pelayanan Kesehatan. Jurnal Kesehatan Masyarakat, 5(1), pp. 1-8.

Rahmawati, D., Pamungkas, A., Aulia, B.U., Larasati, K.D., Rahadyan, G.A., \& Dito, A.H., 2016. Participatory Mapping for Urban Fire Risk Reduction in High-density Urban Settlement. Procedia - Social and Behavioral Sciences. Elsevier B.V., 227(November 2015), pp. 395-401.

Tofiło, P., Konecki, M., Galaj, J., Jasklowsi, W., Tusnio, N., \& Cisek, M., 2013. Expert System for Building Fire Safety Analysis and Risk Assessment, in Procedia Engineering. pp. 1156-1165.

Windraswara, R., 2009. Keterlibatan Komunitas Dalam Perencanaan Sanitasi Pada Daerah Rawan Bencana. Jurnal Kesehatan Masyarakat, 5(1), pp. 58-63.

Xin, J., \& Huang, C., 2013. Fire Risk Analysis of Residential Buildings Based on Scenario Clusters and Its Application in Fire Risk Management. Fire Safety Journal, 62(part A).

Zhang, C., 2018. Analysis of Fire Safety System for Storage Enterprises of Dangerous Chemicals. Procedia Engineering, 211, pp. 986-995.

Zhang, X. H., Guan, Y.X., Fang, Z., \& Liao, Y.F., 2016. Fire Risk Analysis and Prevention of Urban Comprehensive Pipeline Corridor. Procedia Engineering. Elsevier B.V., 135, pp. 462-467. 